\title{
Evaluation of GPFARM for Simulation of Forage Production and Cow-Calf Weights
}

\author{
Allan A. Andales, ${ }^{1}$ Justin D. Derner, ${ }^{2}$ Patricia N. S. Bartling, ${ }^{3}$ \\ Lajpat R. Abuja, ${ }^{4}$ Gale H. Dunn, ${ }^{1}$ Richard H. Hart, ${ }^{5}$ \\ and Jon D. Hanson 6 \\ Authors are ${ }^{1}$ Soil Scientists, ${ }^{3}$ Agronomist, and ${ }^{4}$ Soil Scientist/Research Leader, Great Plains Systems Research Unit, 2150 Centre \\ Ave, Bldg D, Suite 200, Fort Collins, CO 80526; ${ }^{2}$ Rangeland Scientist and ${ }^{5}$ Rangeland Scientist (retired), USDA-Agricultural \\ Research Service, High Plains Grasslands Research Station, 8408 Hildreth Road, Cheyenne, WY 82009; and ${ }^{6}$ Rangeland Scientist/ \\ Lab Director, USDA-Agricultural Research Service, Northern Great Plains Research Laboratory, Mandan, ND 58554
}

\begin{abstract}
A modeling approach that assesses impacts of alternative management decisions prior to field implementation would reduce decision-making risk for rangeland and livestock production system managers. However, the accuracy and functionality of models should be verified before they are used as decision-making tools. The goal of this study was to evaluate the functionality of the Great Plains Framework for Agricultural Resource Management (GPFARM) model in simulating forage and cow-calf production in the central Great Plains. The forage production module was tested in shortgrass prairie using April-October monthly biomass values from 2000 through 2002 for warm-season grasses (WSG), cool-season grasses (CSG), shrubs, and forbs. The forage module displayed excellent (99\% explained variance) agreement in the 2001 calibration year in tracking growth and senescence trends of WSG and CSG, which constitute the vast majority of the aboveground biomass. Less agreement $(35 \%-39 \%$ explained variance) was observed for shrubs and forbs. The model-explained variances of biomass in 2000 and 2002 (verification years) were $80 \%$ for WSG, $67 \%$ for CSG, $78 \%$ for shrubs, and $82 \%$ for forbs. Further development is needed to improve predicted plant response to environmental stresses. The cow-calf production module was tested in northern mixed-grass prairie using June-November monthly average cow and calf weights from 1996 through 2001 for March-calving, moderately stocked Hereford pairs. Overall, GPFARM performed well and tracked cow ( $81 \%$ explained variance) and calf ( $94 \%$ explained variance) pre- and postweaning weights. The GPFARM model has functional utility for simulating forage and cow-calf production with satisfactory accuracy at semiarid-temperate sites, such as southeastern Wyoming and northeastern Colorado. Continued development will focus on improving plant response to environmental stresses and testing the model's functionality as a decision support tool for strategic and tactical ranch management.
\end{abstract}

\section{Resumen}

Una metodología de modelaje que evalúe los impactos de decisiones alternativas de manejo antes de su implementación en campo reduciría el riesgo de la toma de decisión para los manejadores del sistema de pastizal y producción de ganado. Sin embargo, la certeza y funcionalidad de los modelos debe ser verificadas antes de que ellos sean usados como herramientas de toma de decisiones. La meta de este estudio fue evaluar la funcionalidad del modelo "Marco de las Grandes Planicies para el Manejo de los Recursos Agrícolas"(GPFARM) para simular la producción de forraje y vaca-becerro en las Grandes Planicies del Centro. El módulo de producción de forraje fue probado en una pradera de zacates cortos usando valores mensuales de Abril a Octubre del 2000 al 2002 de biomasa de zacates de estación caliente (WSG), zacates de estación fría (CSG), arbustos y hierbas. En el año de calibración de 2001, el modulo de forraje mostró una excelente concordancia (explicó 99\% de la varianza) en el monitoreo de la tendencia de crecimiento y senescencia de WSG y CSG, los cuales constituyen la vasta mayoría de la biomasa aérea. Para el caso de arbustos y hierbas se observó una menor concordancia (explicó el 35\%-39\% de la varianza). La explicación de las varianza de la biomasa por el modelo en el 2000 y 2002 (años de verificación) fue $80 \%$ para WSG, 67\% para CSG, 78\% para arbustos y $82 \%$ para hierbas. Se necesita mas desarrollo para mejorar la predicción de la respuesta de la planta a factores ambientales de estrés. El módulo de producción de vaca-becerro se probo en una pradera de zacates mixtos del norte usando los promedios mensuales de peso de pares de vacas-becerros Herford de pariciones de Marzo del periodo de 1996-2001 con una carga animal moderada. En general, el GPFARM funcionó bien y rastreó los pesos de las vacas (explicó $81 \%$ de la varianza) y becerros (explicó $94 \%$ de la varianza)antes y después del destete. El modelo GPFARM tiene una utilidad funcional para simular la producción de forraje y vaca-becerro con una certeza satisfactoria en los sitios semiáridos templados, como el sudeste de Wyoming y nordeste de Colorado. El próximo desarrollo se enfocará en mejorar la respuesta de la planta a factores ambientales de estrés y en probar la funcionalidad del modelo como una herramienta de soporte para la toma de decisiones estratégicas y tácticas del manejo del rancho.

Key Words: central Great Plains, simulation model, northern mixed-grass prairie, shortgrass prairie, cow-calf production

Correspondence: Allan A. Andales, USDA-Agricultural Research Service, Great Plains Systems Research Unit, 2150 Centre Ave, Bldg D, Suite 200, Fort Collins, C0 80526. Email: allan.andales@ars.usda.gov

Manuscript received 5 January 2004; manuscript accepted 6 November 2004. 


\section{INTRODUCTION}

Proper management of forage and cattle production on rangelands requires an understanding of the environmental and livestock interactions that affect productivity. Comparisons of alternative management practices for rangeland and livestock production systems are difficult to perform because of the size and variability of the land management units and the complexity of herd dynamics. A modeling approach for evaluating rangeland and livestock systems allows managers to assess the impacts of alternative management practices prior to actual field implementation, thereby reducing risks in decision-making. Previous models such as SMART (Hart 1989), SPUR (Wight and Skiles 1987), and SPUR2 (Hanson et al. 1992) have been developed for this very purpose.

The US Department of Agriculture-Agricultural Research Service (USDA-ARS) Great Plains Systems Research Unit, in a collaborative effort with Colorado State University, developed the Great Plains Framework for Agricultural Resource Management (GPFARM) decision support system (Ascough et al. 2002; Shaffer et al. 2000). The general purpose of GPFARM is to serve as a whole farm/ranch decision support system in strategic planning across the Great Plains, for production, economic, and environmental-impact analysis and site-specific database generation, from which alternative agricultural management systems can be tested and compared. Limited testing of the crop production modules has been done (Andales et al. 2003; McMaster et al. 2002, 2003) but the forage and cattle production modules have not been tested. Therefore, our goal in this study was to evaluate the functionality of GPFARM in simulating forage and cow-calf production using readily available forage and cow-calf data from the central Great Plains, which is the immediate target area for GPFARM. The specific objectives were 1) to evaluate GPFARM predictions of forage production compared to monthly observations of forage biomass taken from a shortgrass steppe site in northeastern Colorado during the 2000-2002 growing seasons and 2) to evaluate GPFARM predictions of cow and calf weights compared to monthly observations of cow-calf herds moderately stocked on northern mixed-grass prairie in southeastern Wyoming during the 1996-2001 growing seasons.

\section{MATERIALS AND METHODS}

\section{GPFARM Forage Module}

The forage module of GPFARM is a simplification of the SPUR2 model (Hanson et al. 1992). Live and dead forage are simulated for 5 functional groups (warm-season grasses, cool-season grasses, forage legumes, shrubs, and unpalatable forbs) rather than for individual species. The proportion of the plant community in each functional group (PropPop, 0-1) is specified by the user and should add up to 1.0. At the start of simulation, the PropPop values are used to partition the initial total biomass among the functional groups. Biomass production for each functional group is calculated based on a potential growth rate that is adjusted by non-dimensional scalar multipliers for temperature and water stress factors:

$$
\Delta W=\text { GrRate (AboveBio) }(E V P)
$$

where $\Delta W$ is daily change in biomass $\left(\mathrm{kg} \cdot \mathrm{ha}^{-1} \cdot \mathrm{day}^{-1}\right)$, GrRate is potential growth rate $\left(\mathrm{kg} \cdot \mathrm{kg}^{-1} \cdot \mathrm{day}^{-1}\right)$, AboveBio is aboveground live biomass $\left(\mathrm{kg} \cdot \mathrm{ha}^{-1}\right)$ and EVP is the environmental fitness factor (0-1) affecting forage production. Environmental fitness is quantified by the following equation:

$$
E V P=E T P \cdot E W P
$$

where ETP is effect of temperature on production (0-1) and $E W P$ is effect of water availability on production (0-1). Hanson et al. $(1987,1988)$ discuss the empirical bases for the functions and the reader is referred to them for a detailed description. The ETP function is an empirical bell-shaped curve with minimum (Tmin), optimum (Topt), and maximum (Tmax) temperatures for growth determining its shape. The EWP is a threshold-response curve that is a function of the ratio of actual evapotranspiration (ET) and potential ET. The current version of GPFARM does not explicitly consider nitrogen (N) stress on rangeland. This was not considered a major limitation in the current study because the simulated systems were natural rangelands with no commercial $\mathrm{N}$ fertilization, and they were presumed to have stable, albeit low, plant-available $\mathrm{N}$ levels. Also, the effect of $\mathrm{N}$ stress is implicitly considered in the calibration of potential growth rate $(\mathrm{GrRate})$ of each functional group. Plant respiration $\left(\mathrm{kg} \cdot \mathrm{ha}^{-1} \cdot \mathrm{day}^{-1}\right)$ is estimated by the following:

$$
\text { Respiration }=\text { RespRate } \cdot W_{s}
$$

where RespRate is relative respiration rate $\left(0.04 \mathrm{~kg} \cdot \mathrm{kg}^{-1}\right.$ shoot biomass $\cdot$ day $^{-1}$ ) and $W_{s}$ is current biomass stored in the shoot $\left(\mathrm{kg} \cdot \mathrm{ha}^{-1}\right)$. Daily net assimilation by each functional group is the difference between $\Delta W$ and Respiration. The upper boundary of total aboveground biomass (sum of all functional groups) is determined by the maximum forage production potential of the site $\left(\right.$ MaxForg, $\left.\mathrm{kg} \cdot \mathrm{ha}^{-1}\right)$.

Senescence is also simulated by the use of a parameterized senescence rate $\left(\right.$ SenEarly, $\left.\mathrm{kg} \cdot \mathrm{kg}^{-1} \cdot \mathrm{day}^{-1}\right)$ that takes effect after a specified day of the year (SenDay, day of year). After senescence, aboveground biomass falls to the soil surface as litter at a parameterized rate $\left(\right.$ FallRate, $\left.\mathrm{kg} \cdot \mathrm{kg}^{-1} \cdot \mathrm{day}{ }^{-1}\right)$. Root biomass is calculated by multiplying total aboveground biomass (sum of all functional groups) by the root:shoot ratio and assuming an exponential distribution in the soil profile (Weaver et al. 1935; Gill et al. 1999).

\section{GPFARM Cattle Module}

The cattle module of GPFARM is a simplification of the SPUR2 cattle module (Hanson et al. 1992). The GPFARM module can only simulate cow-calf operations on native rangelands. It includes default databases with parameter sets for common cattle breeds. The module components include herd size and animal production. The module simulates a herd rather than individual animals and the herd size estimate includes numbers of animals in the following classes: pregnant and nonpregnant (open) cows, replacement heifers, steer and heifer calves, and bulls. The cattle production component consists of 1) estimating average daily weight gain or loss for each cattle class, 2) estimating milk production for lactating cows, and 3) producing a calf crop for annual sale. 
The herd size component responds to user-specified stocking rate, calving date, weaning date, date of sale of calves and open cows, and heifer replacement rate. The production component calculates the demand for forage by animal class, assesses availability of forage and supplements (and milk, in the case of calves), calculates intake, and produces animal weight gain or loss from intake. Food demand and supply are expressed in terms of total digestible nutrients (TDN). Animal demand $(D M D)$ for food by each animal class is estimated by the following:

$$
D M D=a \cdot \text { Weight }^{0.9}+\text { gain }
$$

where $a$ is an empirical constant (0.025-0.029), Weight is the weight of the animal $(\mathrm{kg})$ at the start of the day, and gain is the potential daily gain $(\mathrm{kg})$ of each animal class. Potential daily gain of cows is set equal to daily milk production (MilkProd, $\mathrm{kg} \cdot \mathrm{TDN} \cdot \mathrm{day}^{-1}$ ) while that of calves is determined by the following equation:

$$
\text { gain }=\frac{\text { Wean Wt }- \text { BrthWt }}{\text { WeanD } y-B r t h D y} * \text { Cond }
$$

where Wean Wt is calf target weaning weight $(\mathrm{kg}), B r t h W t$ is calf birth weight $(\mathrm{kg})$, WeanDy is weaning day (day of year), $B r t h D y$ is calf birth day (day of year), and Cond is the cow body condition factor (0-1) that represents the effect of cow body condition on milk supply. The cow body condition is estimated as follows:

$$
\text { Cond }=\frac{\text { Weight }+25}{\text { Mature Wt }} ; \quad \text { Cond } \leq 1.0
$$

where Weight is current weight of cow $(\mathrm{kg})$ and Mature Wt is the weight of a mature nonstressed cow $(\mathrm{kg})$. Total herd demand (TotDemand) is estimated by summing up the animal class demands:

$$
\text { TotDemand }=\frac{\sum_{i} \text { CntAnimals }_{i} * D M D_{i}}{1000}
$$

where CntAnimals $s_{i}$ is the number of heads in animal class $i$, $D M D_{i}$ is the demand for food by animal class $i(\mathrm{~kg})$, and 1000 is a conversion factor to metric ton.

Animal demand is first met by grazing available forage. Cattle preference values (1.0 being the highest preference) for plant functional groups are set at 0.9 for cool-season grasses and legumes, 0.4 for warm-season grasses, 0.2 for shrubs, and 0.0 for unpalatable forbs. Relative abundance of the plant functional groups on the management unit combined with aforementioned preference values determines desirability as cattle forage. The amount of daily available forage is reduced using the proper use factor UseCrit ( $\mathrm{kg}$ consumed $\cdot \mathrm{kg}^{-1}$ total forage) specified by the user. If the available forage does not meet animal demand, supplements are consumed according to a least-cost feed ration determined by a linear program that is available in the model or according to user-specified percentages of selected supplements. Total daily dry matter intake (TotIntake, $\mathrm{kg}$ ) for each cattle class is estimated in the following way:

$$
\text { TotIntake }=\text { InSup }+ \text { InForage }+ \text { InMilk }
$$

where InSup is daily intake from available supplements $(\mathrm{kg})$, InForage is daily intake from available forage ( $\mathrm{kg})$, and InMilk is daily intake $(\mathrm{kg})$ from milk (only for calves that have not been weaned). It is possible that DMD is greater than Intake (e.g. available forage may be inadequate and supplements set to zero), in which case the potential daily gain is not attained. Metabolic maintenance requirement (Maint, $\mathrm{kg} \cdot \mathrm{TDN}$ ) is estimated by the following empirical functions:

Maint $=\frac{1.0024+0.0052 \text { Weight }+ \text { MilkProd }}{\text { Dig }} \quad$ (Lactating cow $)$

Maint $=0.75 D M D \quad$ (Calf)

where Weight and DMD are as previously defined, MilkProd is daily milk production of a cow $\left(\mathrm{kg} \cdot \mathrm{TDN} \cdot \mathrm{day}^{-1}\right)$, and $\mathrm{Dig}$ is diet digestibility $(0-1)$ calculated in the following way:

$$
D i g=\frac{\left(\sum_{i} \text { InSup }_{i}\right) \text { QualSup }+\left(\sum_{j} \text { InForage }_{j}\right) \text { QualForage }}{\sum_{i} \text { InSup }_{i}+\sum_{j} \text { InForage }_{j}}
$$

where $\operatorname{InSup}_{i}$ is intake of supplement type $i(\mathrm{~kg})$, InForage $_{j}$ is intake of forage type $j(\mathrm{~kg})$, Qualsup is the quality of supplement (1.0 being the highest), and QualForage is the quality of forage. They are calculated with the following equations:

$$
\begin{aligned}
\text { Qualsup } & =\sum_{i}\left(\text { SupTDN }_{i} * \text { Ration }_{i}\right) \\
\text { QualForage } & =\sum_{j}\left(\text { ForTDN }_{j} * \text { RelPref }_{j}\right)
\end{aligned}
$$

where $\operatorname{SupTDN}_{i}$ is the TDN value of supplement type $i(0-1)$, Ration $_{i}$ is the fraction of the ration composed of supplement $i$ $(0-1)$, ForTDN $_{j}$ is the TDN value of forage $j(0-1)$, and RelPref $f_{j}$ is the relative preference for forage $j(0-1)$. Weight gain or loss for each cattle class is determined by calculating the daily TDN requirement, which can be met by either forage or supplemental feeds or a combination of both. The average weight for each cattle class $(C W)$ is estimated daily by the following calcuation:

$$
C W=C W_{i}+\text { TotIntake }- \text { Maint }
$$

where $C W_{i}$ is initial class weight at the start of the day $(\mathrm{kg})$, TotIntake and Maint are as previously defined. The nutritional demand of calves is first supplied by milk. If milk supply is insufficient, the model then simulates forage consumption and, lastly, supplement consumption if that is available and grazing is still insufficient.

\section{Simulation of Forage Production}

The forage production module was tested in the shortgrass prairie ecosystem at the USDA-ARS Central Plains Experimental Range near Nunn, Colorado (lat $40^{\circ} 49^{\prime} \mathrm{N}$, long $107^{\circ} 46^{\prime} \mathrm{W}$ ). Mean annual precipitation is $321 \mathrm{~mm}$, and mean annual temperature is $8.6^{\circ} \mathrm{C}$ (Lauenroth and Sala 1992). The dominant soil at the site is Olney fine sandy loam and the profile characteristics were taken from the GPFARM soil database (derived from merged Natural Resource Conservation Service Soils-5 and Soils- 6 databases). As much as possible, the goal was to test the forage module independent of the cattle module. 
Table 1. Critical forage parameters used in GPFARM simulations.

\begin{tabular}{|c|c|c|c|c|c|}
\hline \multirow[b]{2}{*}{ Parameter } & \multirow[b]{2}{*}{ Definition } & \multicolumn{4}{|c|}{ Functional Group } \\
\hline & & $\begin{array}{l}\text { Warm- } \\
\text { Season } \\
\text { Grasses }\end{array}$ & $\begin{array}{l}\text { Cool- } \\
\text { Season } \\
\text { Grasses }\end{array}$ & Shrubs & Forbs \\
\hline $\begin{array}{l}\text { GrRate } \\
\qquad\left(\mathrm{kg} \cdot \mathrm{kg}^{-1} \cdot \text { day }^{-1}\right)\end{array}$ & $\begin{array}{r}\text { Relative growth } \\
\text { rate of shoot }\end{array}$ & 0.90 & 0.26 & 0.17 & 0.20 \\
\hline $\operatorname{Tmax}\left({ }^{\circ} \mathrm{C}\right)$ & $\begin{array}{l}\text { Maximum temperature } \\
\text { for growth }\end{array}$ & 45 & 36 & 36 & 35 \\
\hline Topt $\left({ }^{\circ} \mathrm{C}\right)$ & $\begin{array}{l}\text { Optimum temperature } \\
\text { for growth }\end{array}$ & 37 & 22 & 21 & 23 \\
\hline $\operatorname{Tmin}\left({ }^{\circ} \mathrm{C}\right)$ & $\begin{array}{l}\text { Minimum temperature } \\
\text { for growth }\end{array}$ & 9 & 3 & 4 & 3 \\
\hline SenDay (DOY) & Day senescence begins & 195 & 190 & 160 & 175 \\
\hline $\begin{array}{l}\text { SenEarly } \\
\qquad\left(\mathrm{kg} \cdot \mathrm{kg}^{-1} \cdot \text { day }^{-1}\right)\end{array}$ & $\begin{array}{l}\text { Rate of tissue dying in } \\
\text { the growing season }\end{array}$ & 0.014 & $\quad 0.013$ & 0.001 & 0.001 \\
\hline $\begin{array}{l}\text { FallRate } \\
\qquad\left(\mathrm{kg} \cdot \mathrm{kg}^{-1} \cdot \text { day }^{-1}\right)\end{array}$ & $\begin{array}{l}\text { Rate that standing dead } \\
\text { biomass falls and } \\
\text { becomes residue }\end{array}$ & 0.010 & 0.010 & 0.001 & 0.010 \\
\hline
\end{tabular}

Therefore, we selected a forage data set taken from an area ungrazed during 2 out of the 3 years of available record. Green aboveground biomass was sampled from a 3.9-hectare $(60 \mathrm{~m} \times 650 \mathrm{~m})$ area consisting of 15 plots, each measuring $20 \mathrm{~m} \times 130 \mathrm{~m}$, arranged in 5 columns and 3 rows (VanAmburg 2003). Samples were taken approximately every 30-40 days from mid-April to mid-October during 2000-2002, resulting in 6 to 7 sample dates per year. At each sampling date, biomass samples were taken from 9 quadrats, each $1 \times 1 \mathrm{~m}$ and randomly located in plots, in 3 columns randomly selected within each row. The samples were sorted into 5 functional groups. The 9 biomass samples for each functional group were averaged for comparison with GPFARM simulated values at each sampling date.

From 2000 to 2002 , air temperature $\left({ }^{\circ} \mathrm{C}\right)$, photosynthetically active radiation $\left(\mathrm{PAR}, \mu \mathrm{mol} \cdot \mathrm{s}^{-1} \cdot \mathrm{m}^{-2}\right)$, precipitation $(\mathrm{mm})$, relative humidity $(\%)$, and wind speed $\left(\mathrm{m} \cdot \mathrm{s}^{-1}\right)$ were recorded on site at 20-minute intervals (D. Smith, personal communication, 2003). Because GPFARM requires only daily weather data, daily maximum and minimum air temperatures were extracted from the 20-minute data; daily solar radiation $(\approx \mathrm{PAR} / 0.47$; assuming that $\mathrm{PAR}$ is $47 \%$ of incident solar radiation) and precipitation were calculated by summing over a 24-hour period; average daily relative humidity and wind speed were calculated by averaging over a 24 -hour period. The 24-hour period was from midnight-to-midnight. Daily precipitation is used in GPFARM to calculate infiltration and soil water redistribution by the method described by Andales et al. (2003). Daily solar radiation, relative humidity, and wind speed are used to estimate potential ET by the extended Shuttleworth-Wallace method (Farahani and Ahuja 1996).

Any plant growth model is best calibrated under nonstress or minimum-stress conditions because input plant parameters usually characterize potential or maximum growth. Thus data from 2001 were used to calibrate the GPFARM forage parameters as the site was ungrazed and the precipitation was more favorable (April-September: $297 \mathrm{~mm}$ ) than in either 2000
Table 2. Year- and site-specific forage parameters for GPFARM simulations in shortgrass prairie at the Central Plains Experimental Range, Nunn, Colorado.

\begin{tabular}{|c|c|c|c|c|c|}
\hline \multirow{2}{*}{$\begin{array}{l}\text { Year-Specific } \\
\text { Parameters }\end{array}$} & \multirow{2}{*}{\multicolumn{2}{|c|}{ Definition }} & \multicolumn{3}{|c|}{ Year } \\
\hline & & & 2000 & 2001 & 2002 \\
\hline $\begin{array}{l}\text { MaxForg } \\
\qquad\left(\mathrm{kg} \cdot \mathrm{ha}^{-1}\right)\end{array}$ & Maximı & production & 1200 & 1500 & 424 \\
\hline $\begin{array}{l}\text { PropPopWSG } \\
\quad \text { (proportion) }\end{array}$ & $\begin{array}{r}\text { Proport } \\
\text { by } w\end{array}$ & $\begin{array}{l}\text { age composed } \\
\text { on grasses }\end{array}$ & 0.53 & 0.64 & 0.59 \\
\hline $\begin{array}{l}\text { PropPopCSG } \\
\text { (proportion) }\end{array}$ & $\begin{array}{r}\text { Proport } \\
\text { by } c c\end{array}$ & $\begin{array}{l}\text { age composed } \\
\text { grasses }\end{array}$ & 0.15 & 0.23 & 0.12 \\
\hline $\begin{array}{l}\text { PropPopShb } \\
\quad \text { (proportion) }\end{array}$ & $\begin{array}{r}\text { Proport } \\
\text { by st }\end{array}$ & age composed & 0.11 & 0.06 & 0.01 \\
\hline $\begin{array}{l}\text { PropPopFb } \\
\text { (proportion) }\end{array}$ & $\begin{array}{r}\text { Propor } \\
\text { by u }\end{array}$ & $\begin{array}{l}\text { age composed } \\
\text { forbs }\end{array}$ & 0.21 & 0.07 & 0.28 \\
\hline \multicolumn{2}{|c|}{$\underline{\text { Site-Specific Parameters }}$} & \multicolumn{2}{|c|}{ Definition } & & Value \\
\hline \multicolumn{2}{|c|}{ MxCover (proportion) } & \multicolumn{2}{|c|}{ Maximum ground cover } & & 0.48 \\
\hline \multicolumn{2}{|c|}{$\operatorname{MxLAI}\left(m^{2} \cdot m^{-2}\right)$} & \multicolumn{2}{|c|}{ Maximum leaf-area index } & & 2.0 \\
\hline \multicolumn{2}{|c|}{ UseCrit (proportion) } & \multicolumn{3}{|c|}{$\begin{array}{l}\text { Proper use factor, maximum } \\
\text { forage depletion }\end{array}$} & 0.5 \\
\hline
\end{tabular}

(249 $\mathrm{mm}$ ) or $2002(183 \mathrm{~mm})$. The parameters were adjusted to get the best fit of the biomass curves for each functional group (Tables 1 and 2). The magnitude and timing of peak growth were most sensitive to GRate and Topt. Monson et al. (1983, 1986) provided ranges of Topt for warm-season and coolseason grasses that typically dominate the study site. The SenDay and SenEarly parameters had the greatest influence on biomass decline and were adjusted to obtain the best fit for the declining phase of the curves. Forage legumes were nominally present and were disregarded in the simulations. Data from 2000 and 2002 were used for model verification. The site was ungrazed in 2002 but was moderately grazed in $2000\left(5.6\right.$ ha $\cdot$ heifer $\left.^{-1}\right)$. The 28.1 -ha pasture area and 5 heifers were input into the model for that year.

The 3 years of forage production were simulated separately in GPFARM (i.e. simulation was not continuous over the 3 years). The biomass readings taken on the April sampling date of each year were used as initial values at the start of each simulation. Predicted forage biomass on each subsequent sampling date (5-6 per year) was compared to observed data for each functional group.

\section{Simulation of Cow-Calf Production}

The cattle module, while limited to cow-calf operations, provides various management options (e.g. stocking rate, rotational grazing, and birth, wean, and sale dates) that can then be compared in terms of calf production, forage production, and supplement costs. However, we found it difficult to find readily available experimental data that included detailed measurements of both cow-calf weight gains and within-season forage production of the grazed area with these various management options tested.

Experimental data from the Sustainable Rangeland-Based Beef Cattle Production Systems project conducted from 1996 to 2001 at the USDA-ARS High Plains Grasslands Research 
Station in Cheyenne, Wyoming (lat $41^{\circ} 11^{\prime} \mathrm{N}$, long $104^{\circ} 53^{\prime} \mathrm{W}$ ) were used to test monthly cow and calf weight simulations. This data set was characterized as March-calving-moderate-stocking management and represents the most common practice in the region. The climate at the site is semiarid with an average annual precipitation of $384 \mathrm{~mm}$. Precipitation is lowest in December, increasing to a maximum in late May and early June; it remains moderate until fall, when it decreases again to a December minimum (Stevenson et al. 1984). Daily climate data were taken from the GPFARM historical climate database (extracted from National Climate Data Center databases) for Cheyenne, Wyoming. Soil profile characteristics of Ascalon loam, which is the dominant soil at the site, were obtained from the High Plains Grasslands Research Station Detailed Soil Survey (Stevenson et al. 1984) for input to GPFARM. Hereford cow-calf pairs (10-17, varying by year) were stocked on native northern mixed-grass prairie from June to November at 5.2 to 8.8 ha $\cdot$ pair $^{-1}$ (varying by year) without supplement. The pasture area was 88 ha. Available forage consisted of warm-season grasses, cool-season grasses, and forbs. Cow and calf weights were recorded monthly, thus giving 6 to 7 readings for each year.

The model was run each year beginning on the average birth date of calves (BrthDy, Table 3). Average breed-specific and year-specific model parameters were calculated from the 19962001 data set (Table 3). The number of pregnant cows (PregCows, Table 3) was specified and the model simulated calving on the first day of simulation. The cows were fed 9 $\mathrm{kg} \cdot \mathrm{head}^{-1} \cdot \mathrm{day}^{-1}$ of mature alfalfa hay and supplemented with $0.7 \mathrm{~kg} \cdot$ head $^{-1} \cdot$ day $^{-1}$ of cottonseed cake feed supplements from the first simulation day to the start of grazing native forage. In the model, these were input at the given rates with $0.50 \mathrm{~kg} \cdot \mathrm{TDN} \cdot \mathrm{kg}^{-1}$ and $0.90 \mathrm{~kg} \cdot \mathrm{TDN} \cdot \mathrm{kg}^{-1}$ feed values for alfalfa hay and cottonseed, respectively. The above ration was characterized as $93 \%$ alfalfa hay and $7 \%$ cottonseed by weight. It is important to note that the cattle module was designed with the goal of achieving a user-specified target weaning weight for calves; thus, by default GPFARM automatically provides supplements if available when forage supply is inadequate. However, it is possible to simulate animal weight gains based on grazing alone by setting available supplements to zero during the grazing period. In this case, the target weaning weight may not be achieved and animal weight losses may occur in the simulation.

Observed monthly forage biomass measurements were lacking, but an estimate of peak standing crop of herbage was available each year. The highest value was 2027 $\mathrm{kg} \cdot \mathrm{ha}^{-1}$, recorded in 2001 and used as the maximum forage production parameter (MaxForg in Table 2) in the simulations. The plant community composition was taken from a climax description (Stevenson et al. 1984) of the site as follows (See Table 2 for definitions): PropPopWSG $=0.30$, PropPopCSG $=0.55, \quad$ PropPopFb $=0.15$. Forage legumes and shrubs were rare. Except for the above-mentioned parameters, all other forage parameters were the same as the calibrated values from the previous section (See Tables 1 and 2). The parameters GrazStart and GrazEnd (Table 3) indicate the actual dates the herd was put on and taken off the rangeland site. During the period GrazStart to GrazEnd, the cattle grazed only on available forage and were not given supplements.
Table 3. Hereford breed- and year-specific cattle parameters for the GPFARM simulations at the USDA-ARS High Plains Grasslands Research Station, Cheyenne, Wyoming.

\begin{tabular}{|c|c|c|c|c|c|c|c|}
\hline \multicolumn{8}{|l|}{ Breed-Specific } \\
\hline Parameter & \multicolumn{6}{|c|}{ Definition } & Value \\
\hline MatureWt (kg) & \multicolumn{6}{|c|}{$\begin{array}{l}\text { Average (avg.) weight of mature } \\
\text { pregnant cow }\end{array}$} & 471 \\
\hline BrthWt (kg) & \multicolumn{6}{|c|}{ Avg. birth weight of calves } & 42 \\
\hline $\begin{array}{l}\text { MilkProd } \\
\qquad\left(\mathrm{kg} \cdot \mathrm{TDN} \cdot \text { day }^{-1}\right.\end{array}$ & \multicolumn{6}{|c|}{ Mean milk production of each cow } & 1.4 \\
\hline Year-Specific & \multirow[b]{2}{*}{ Definition } & \multicolumn{5}{|c|}{ Year } & \\
\hline Parameter & & 1996 & 1997 & 1998 & 1999 & 2000 & 2001 \\
\hline BrthDy (DOY) & $\begin{array}{l}\text { Avg. day of } \\
\text { year of birth }\end{array}$ & 72 & 70 & 76 & 80 & 80 & 62 \\
\hline WeanDy (DOY) & $\begin{array}{l}\text { Avg. day of } \\
\text { year of weaning }\end{array}$ & 256 & 244 & 242 & 246 & 246 & 231 \\
\hline WeanWt (kg) & $\begin{array}{l}\text { Calf weaning } \\
\text { weight goal }\end{array}$ & 213 & 216 & 211 & 203 & 191 & 213 \\
\hline PregCows (no.) & $\begin{array}{l}\text { No. of pregnant } \\
\text { cows }\end{array}$ & 17 & 14 & 14 & 16 & 10 & 14 \\
\hline GrazStart (DOY) & $\begin{array}{l}\text { Day of year grazing } \\
\text { starts }\end{array}$ & 156 & 153 & 173 & 168 & 165 & 163 \\
\hline GrazEnd & $\begin{array}{l}\text { Day of year grazing } \\
\text { ends }\end{array}$ & 322 & 314 & 316 & 314 & 314 & 306 \\
\hline
\end{tabular}

The model was run each year (1996-2001) to simulate cow and calf weights. Because GPFARM simulates average cow and calf weights for a herd and does not track individual animal weights, observed individual cow and calf weights were averaged and compared to the GPFARM simulated average weights.

\section{Model Evaluation}

Time series and one-to-one (1:1) plots between predicted $(p)$ and observed $(o)$ values as well as difference statistics were used in the evaluation of forage and cattle weight simulations. The mean and standard deviation of the model-predicted variable $\left(\bar{p}, s_{p}\right)$ and the observed variable $\left(\bar{o}, s_{o}\right)$ were calculated as well. The following difference statistics were calculated: mean bias error $(M B E)$, root mean square error (RMSE), and index of agreement $(d)$. Mean bias error shows the magnitude of the average over- or under-prediction of the model and is expressed as:

$$
M B E=\frac{\sum_{i=1}^{n}\left(p_{i}-o_{i}\right)}{n}
$$

where $p_{i}$ is the $i^{t h}$ predicted value, $o_{i}$ is the $i^{t h}$ observed value, and $n$ is the number of data pairs.

The RMSE, which shows the average deviation between predicted and observed values regardless of sign, was calculated by using the following equation:

$$
R M S E=\sqrt{\frac{\sum_{i=1}^{n}\left(p_{i}-o_{i}\right)^{2}}{n} .}
$$

The index of agreement, $d$, which gives the proportion of the observed variance that is explained by the model, was 
Table 4. GPFARM performance statistics in the simulation of aboveground live biomass for shortgrass prairie at the Central Plains Experimental Range, Nunn, Colorado.

\begin{tabular}{|c|c|c|c|c|}
\hline & \multicolumn{4}{|c|}{ Functional Group } \\
\hline & $\begin{array}{l}\text { Warm-season } \\
\text { grasses }\end{array}$ & $\begin{array}{c}\text { Cool-season } \\
\text { grasses }\end{array}$ & Shrubs & Forbs \\
\hline \multicolumn{5}{|l|}{ Calibration (2001) } \\
\hline Observed Mean $\left(\mathrm{kg} \cdot \mathrm{ha}^{-1}\right)$ & 285 & 109 & 45 & 44 \\
\hline Predicted Mean $\left(\mathrm{kg} \cdot \mathrm{ha}^{-1}\right)$ & 287 & 114 & 42 & 57 \\
\hline $\operatorname{MBE}^{-1}\left(\mathrm{~kg} \cdot \mathrm{ha}^{-1}\right)$ & 2 & 5 & -3 & 13 \\
\hline $\operatorname{RMSE}\left(\mathrm{kg} \cdot \mathrm{ha}^{-1}\right)$ & 32 & 17 & 20 & 36 \\
\hline$s_{o}\left(\mathrm{~kg} \cdot \mathrm{ha}^{-1}\right)$ & 186 & 98 & 22 & 38 \\
\hline$s_{p}\left(\mathrm{~kg} \cdot \mathrm{ha}^{-1}\right)$ & 170 & 83 & 7 & 12 \\
\hline$d(0-1)$ & 0.99 & 0.99 & 0.39 & 0.35 \\
\hline Observations & 5 & 5 & 5 & 5 \\
\hline \multicolumn{5}{|l|}{ Verification (2000 and 2002) } \\
\hline Observed Mean $\left(\mathrm{kg} \cdot \mathrm{ha}^{-1}\right)$ & 141 & 42 & 15 & 94 \\
\hline Predicted Mean $\left(\mathrm{kg} \cdot \mathrm{ha}^{-1}\right)$ & 113 & 32 & 26 & 89 \\
\hline $\operatorname{MBE}\left(\mathrm{kg} \cdot \mathrm{ha}^{-1}\right)$ & -27 & -9 & 11 & -5 \\
\hline $\operatorname{RMSE}\left(\mathrm{kg} \cdot \mathrm{ha}^{-1}\right)$ & 76 & 33 & 20 & 37 \\
\hline$s_{o}\left(\mathrm{~kg} \cdot \mathrm{ha}^{-1}\right)$ & 92 & 23 & 19 & 56 \\
\hline$s_{p}\left(\mathrm{~kg} \cdot \mathrm{ha}^{-1}\right)$ & 87 & 40 & 26 & 41 \\
\hline$d(0-1)$ & 0.80 & 0.67 & 0.78 & 0.82 \\
\hline Observations & 11 & 11 & 11 & 11 \\
\hline
\end{tabular}

${ }^{1} \mathrm{MBE}$ indicates mean bias error; RMSE, root mean square error; $s_{0}$, standard deviation of observed values; $s_{p}$, standard deviation of predicted values; $d$, index of agreement.

calculated as proposed by Willmott (1981) and Willmott and Wicks (1980):

$$
d=1-\left[\frac{\sum_{i=1}^{n}\left(p_{i}-o_{i}\right)^{2}}{\sum_{i=1}^{n}\left(/ p_{i}^{\prime} /+/ o_{i}^{\prime} /\right)^{2}}\right], \quad 0 \leq d \leq 1
$$

where $p_{i}, o_{i}$, and $n$ are as previously defined, $p_{i}^{\prime}=p_{i}-\bar{o}$, and $o_{i}^{\prime}=o_{i}-\bar{o}$ where $\bar{o}$ is the observed mean and the enclosing slashes $(/ /)$ indicate absolute values. Zero and 1 bound the $d$ statistic, where 1 indicates complete agreement between $p$ and $o$. In the evaluation of model accuracy, the 1:1 line corresponds to perfect agreement between $o$ and $p$ when $p$ is plotted against $o$. While the coefficient of determination $\left(r^{2}\right)$, which is commonly used to report model accuracy, is a measure of the tightness of the linear relationship between $o$ and $p$ relative to the regression line, $d$ is a measure of the tightness of the linear relationship relative to the 1:1 line. The $r^{2}$ can be a misleading measure of accuracy (Willmott 1982), as the regression line can deviate considerably from the 1:1 line; therefore $d$ was used in lieu of $r^{2}$ in this study.

\section{RESULTS AND DISCUSSION}

\section{Forage}

The mean bias errors $(M B E)$ for aboveground green biomass were $2 \mathrm{~kg} \cdot \mathrm{ha}^{-1}$ for warm-season grasses and $5 \mathrm{~kg} \cdot \mathrm{ha}^{-1}$ for cool-season grasses in the calibration year of 2001 (Table 4), and indicated a slight tendency of the model to overpredict biomass. Simulated warm- and cool-season grass biomass

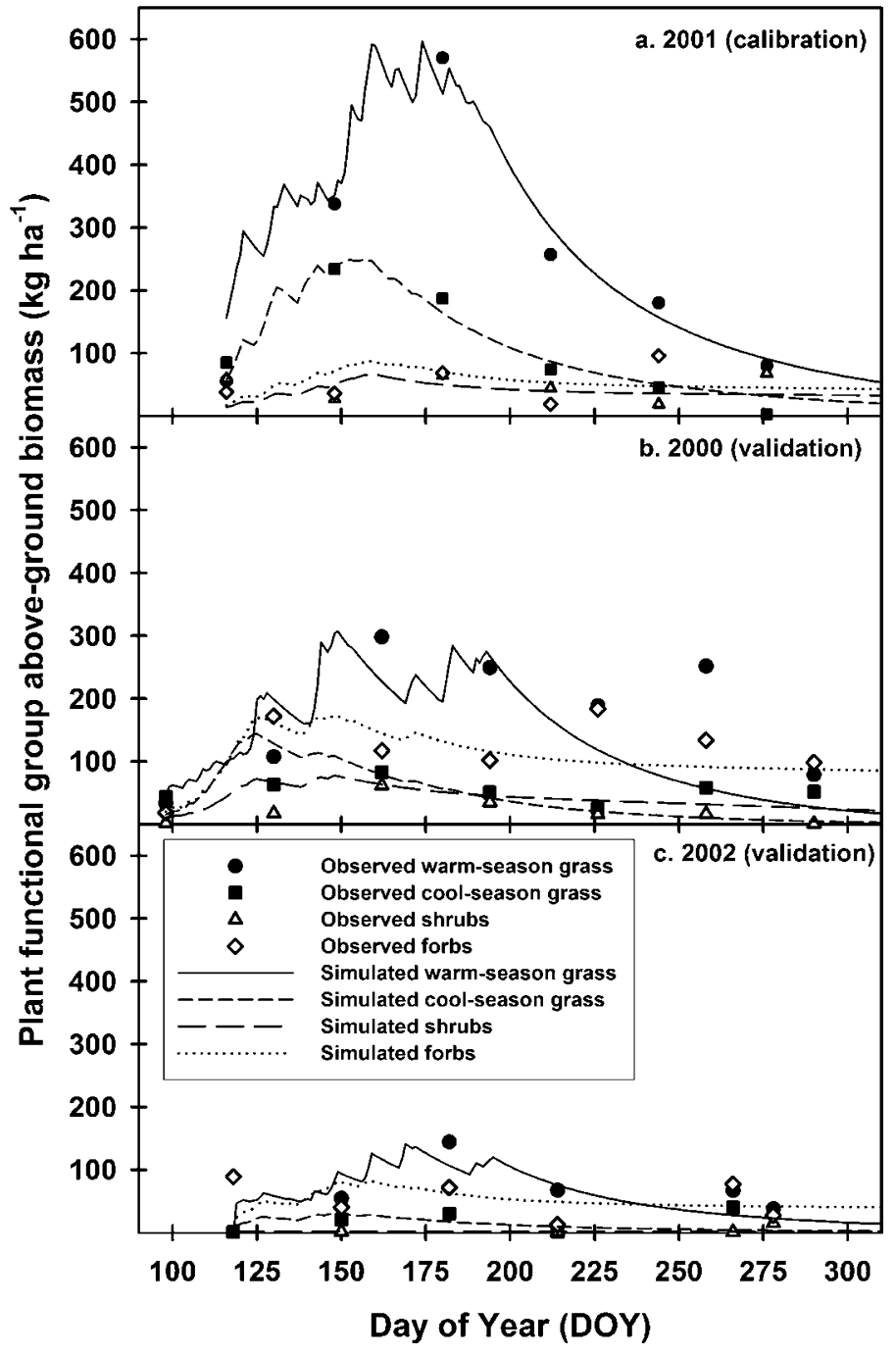

Figure 1. Observed and simulated plant functional group aboveground biomass $\left(\mathrm{kg} \cdot \mathrm{ha}^{-1}\right.$ ) in 2001 (calibration year) and 2000 and 2002 (verification years) in shortgrass prairie at the USDA-ARS Central Plains Experimental Range, Nunn, Colorado.

agreed well with observations in the 2001 calibration year (Fig. 1) as indicated by the very high $d$ values ( 0.99 for both). The simulated biomass of shrubs and forbs in the calibration did not agree well with observed values as indicated by the relatively low $d$ values $(0.35-0.39)$. However, the predicted season mean of shrubs was close to the observed and showed little bias. The model tended to overpredict biomass of forbs $\left(M B E=13 \mathrm{~kg} \cdot \mathrm{ha}^{-1}\right)$. Overall, the model predictions showed less variability than observed $\left(s_{p}<s_{O}\right)$ for all functional groups in the calibration year. Among the 5 functional groups simulated in GPFARM, the warm- and cool-season grasses constitute the majority of cattle diets. The model was able to predict the biomass of warm- and cool-season grasses with a high degree of accuracy $(d=0.99)$ when properly calibrated.

For the verification years (2000 and 2002), the model tended to underpredict biomass of warm-season grasses, cool-season grasses, and forbs (i.e. negative $M B E$ ) and overpredict shrub biomass. Explained variance by the model was greater than $65 \%(d>0.65)$ for all functional groups (Table 4$)$. The RMSE 


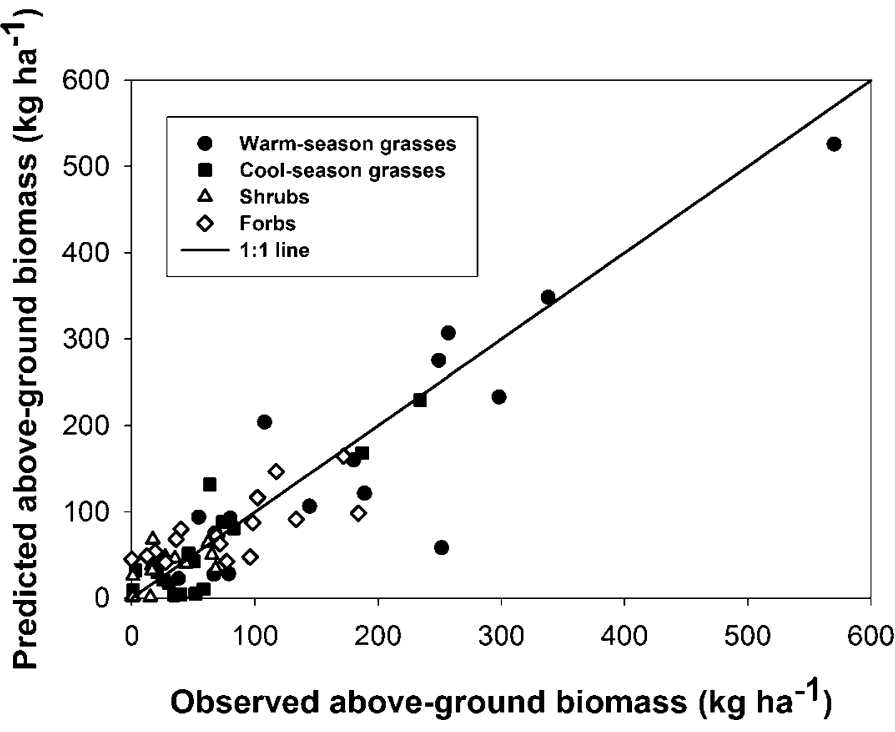

Figure 2. Predicted against the observed values of plant functional group aboveground biomass $\left(\mathrm{kg} \cdot \mathrm{ha}^{-1}\right)$ from 2000 to 2002 in shortgrass prairie at the USDA-ARS Central Plains Experimental Range, Nunn, Colorado.

was highest for warm-season grasses because the model missed a second peak late in the season on day 258 in 2000 (Fig. 1b). Forage production in 2002 (Fig. 1c) was about half of that in 2000 (Fig. 1b) because of much drier conditions in 2002 (AprilSeptember precipitation was $249 \mathrm{~mm}$ in 2000 and $183 \mathrm{~mm}$ in 2002).

Over the 3 years of simulation the $p$ versus $o$ data pairs were generally clustered around the 1:1 line (Fig. 2) except for the observed late-season peak (day 258, Fig. 1b) of warm-season grasses in $2000\left(o=252 \mathrm{~kg} \cdot \mathrm{ha}^{-1}\right)$ that was grossly underpredicted by the model $\left(p=56 \mathrm{~kg} \cdot \mathrm{ha}^{-1}\right)$. A closer look at day 258 in the year 2000 shows observed cool-season grasses and forbs also greater than predicted, but to a lesser degree than the warm-season grasses (Fig. 1b). In the 30-day period prior to day 258, $62 \mathrm{~mm}$ of rainfall had occurred and apparently induced a second peak in forage growth late in the season. However, the forage growth model did not show a positive response to these late-season rainfall events. In order to improve the model's accuracy under these conditions, further testing of the water stress response is needed using a more complete data set that includes soil water content along with biomass observations.

One's perception of model accuracy is highly dependent on scale. Experimental plot data, such as that used in this study, are subject to a high degree of plot-to-plot spatial variability caused by soil variability and heterogeneity of plant communities that are typical of natural rangelands. For example, the coefficient of variation of observed aboveground biomass ( 9 plot samples for each observation date) in the 2001 calibration year ranged from $16 \%$ to $104 \%$ for warm-season grasses, $60 \%$ to $137 \%$ for cool-season grasses, $130 \%$ to $282 \%$ for shrubs, and $91 \%$ to $193 \%$ for unpalatable forbs. On the other hand, GPFARM was developed to operate at the field scale, and both inputs (e.g., soil physical properties) and outputs (e.g., forage production) of the model represent conditions averaged over an entire pasture or management unit. This may partly explain the

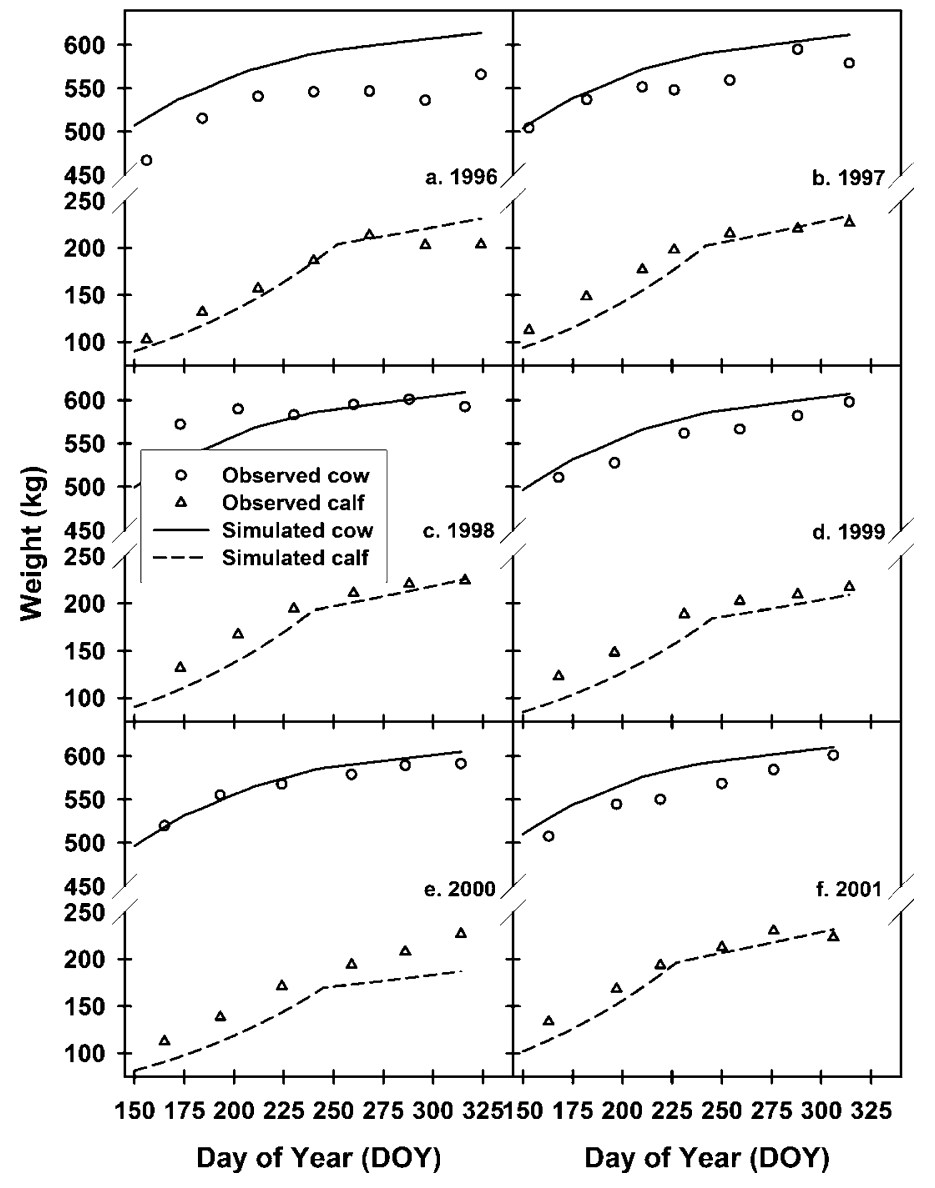

Figure 3. Observed and simulated mean cow and calf weights $(\mathrm{kg})$ for the March calving-moderate stocking treatment in northern mixed-grass prairie at the USDA-ARS High Plains Grasslands Research Station, Cheyenne, Wyoming (1996-2001).

apparent inadequacy of the model in simulating some of the observed variability in forage production.

It was found that the biomass simulations were highly sensitive to the following inputs: initial biomass, proportion (PropPop) of each functional group in the plant community, relative growth rate (GrRate), optimum temperature for growth (Topt), and range site maximum forage production (MaxForg). Therefore, users must provide good estimates of those parameters to obtain good simulations of forage biomass.

\section{Cow-Calf}

Overall, the model predicted the yearly trends in cow and calf weights with good accuracy (Figs. 3 and 4). The model was slightly biased to overpredict cow weights $(M B E=18 \mathrm{~kg}$, Table 5) and underpredict calf weights $(M B E=-16 \mathrm{~kg})$. Over the 6 years of simulation, the model explained $81 \%$ of the variance in cow weights $(d=0.81)$ and $94 \%$ of the variance in calf weights $(d=0.94)$. The model predicted the same variability as observed in cow weights $\left(s_{p}=s_{o}\right)$ but greater variability in calf weights than was observed $\left(s_{p}>s_{o}\right)$.

The RMSE of cow weights (28 kg) was about $40 \%$ higher than that for calves $(20 \mathrm{~kg})$ mainly because of the overpredictions for cows in 1996 (Fig. 3a), underpredictions early in 1998 (Fig. 3c), and the larger magnitudes of the weights. The cows in 1996 


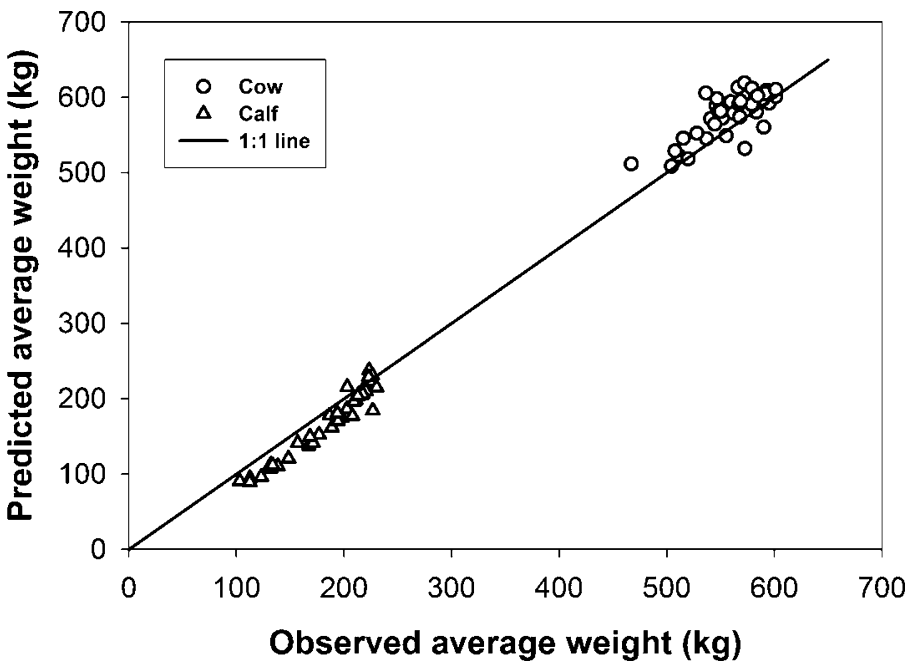

Figure 4. Predicted against the observed values of mean cow and calf weights $(\mathrm{kg})$ for the March calving-moderate stocking treatment in northern mixed-grass prairie at the USDA-ARS High Plains Grasslands Research Station, Cheyenne, Wyoming (1996-2001).

were relatively lighter compared to the other study years. Because the model used the same initial cow weight and the same calf birth weight every year (only birth day and available forage varied from year to year), the model would tend to underpredict weights if the initial observed weights were higher, or overpredict if the initial observed weights were lower.

The model performed well in tracking average cow and calf weights in this study because it was parameterized with the observed average cow weight (6-year average) and yearly average weaning weight, which is used as the target weaning weight in the model. Thus, the model was run with prior knowledge of observed weight-gain curves. In an actual ranch situation where GPFARM is used to predict weights, the user will not have foreknowledge of the weight-gain curves and will parameterize the model based solely on historical information. A user of GPFARM may even use the default values for their particular breed if no historical information is available. Model accuracy is expected to be lower in these situations. The animal simulations in this study do not constitute a validation but rather verify that the mathematical algorithms are adequate for simulation of average cow and calf weights in response to supplement and forage availability.

Calf weight trends were predicted well even after weaning (see inflection points on the calf weight curves, Fig. 3) and indicate that calf forage consumption was properly simulated. Overall, the GPFARM cow-calf module gave satisfactory simulations of animal weights and demonstrated adequate functionality in modeling response of animal weights to forage availability.

\section{MANAGEMENT IMPLICATIONS}

The forage module in GPFARM tracked functional group growth and senescence trends in general with 1 year used to calibrate growth rate and senescence parameters for the shortgrass prairie. It was demonstrated that the simple temperature- and water-driven forage model could accurately predict
Table 5. GPFARM performance statistics in the simulation of cow and calf weights in northern mixed-grass prairie at the USDA-ARS High Plains Grasslands Research Station, Cheyenne, Wyoming (1996-2001).

\begin{tabular}{lcc}
\hline & Cow & Calf \\
\hline Observed Mean $(\mathrm{kg})$ & 559 & 183 \\
Simulated Mean $(\mathrm{kg})$ & 577 & 167 \\
$\mathrm{MBE}^{-1}(\mathrm{~kg})$ & 18 & -16 \\
$\mathrm{RMSE}(\mathrm{kg})$ & 28 & 20 \\
$s_{o}\left(\mathrm{~kg} \cdot \mathrm{ha}^{-1}\right)$ & 32 & 38 \\
$s_{p}\left(\mathrm{~kg} \cdot \mathrm{ha}^{-1}\right)$ & 32 & 45 \\
$d(0-1)$ & 0.81 & 0.94 \\
Observations & 39 & 38
\end{tabular}

${ }^{1}$ MBE indicates mean bias error; RMSE, root mean square error; $s_{0}$, standard deviation of observed values; $s_{p}$, standard deviation of predicted values; $d$, index of agreement.

warm- and cool-season grass biomass with proper calibration. Future work will focus on the module's sensitivity to temperature, water, and nitrogen stresses to gain insight into how the plant growth model behaves under very dry conditions, such as the 2000 and 2002 years at the shortgrass prairie site. Further development of stress algorithms that consider the timing of temperature, water, and nutrient stresses relative to plant phenology could improve plant growth simulations. Maximum productivity for the site and proportion of each functional group entered by the user for the management unit forage resource assisted in adapting the model to local forage production history.

Overall, GPFARM performed well in tracking cow and calf weights pre- and postweaning on native northern mixed-grass prairie. It was verified that the mathematical algorithms are adequate for simulation of average cow and calf weights in response to supplement and forage availability with inputs of average animal characteristics (e.g. birth weight, mature cow weight, etc.) that accurately represented local herd performance. The cow-calf model appears to accomplish its intended strategic goal of producing a calf crop for fall sale with cow and calf weights responsive to forage availability and supplementation. The GPFARM model has functional utility for simulating annual forage and cow-calf production with satisfactory accuracy. Continued development will focus on expanding simulated operations to include stocker steers, adding more cattle marketing and grazing management options, improving plant model response to environmental stresses, validating the model with additional data, and testing the model's functionality as a decision support tool for strategic and tactical ranch management.

\section{AVAILABILITY}

The GPFARM forage and livestock modules are part of the Windows ${ }^{\circledR}$-based GPFARM decision support system that can also be used for whole-farm/ranch simulations and economic analyses. Information on the GPFARM decision support system is available on the Internet at http://infosys.ars.usda.gov/ gpfarm.htm. Ranchers, consultants, and everyone interested in using or testing GPFARM are encouraged to download a free copy (Version 2.6 as of 26 August 2004) from http:// arsagsoftware.ars.usda.gov/gpfarm/registra.htm. A high-speed 
Internet connection is recommended to download the 91megabyte file. Otherwise, a copy may be requested on CDROM at the above web site or by sending an Email to GPSR_Email@ars.usda.gov.

\section{ACKNOWLEDGMENTS}

Dr Mark Weltz furthered development of these modules and was the principal investigator of the NASA-sponsored project from which the forage testing data were obtained. Nam Ho and Bruce Vandenberg provided programming support. Debbie Edmunds and David Smith provided weather data. Lisa VanAmburg, Agnes Przeszlowska, Mary Ashby, and Jeff Thomas clipped biomass samples at the Central Plains Experimental Range. Stanley Clapp and Dale Hill weighed cow-calf pairs at the High Plains Grasslands Research Station.

\section{LITERATURE CITED}

Andales, A. A., L. R. Ahuja, and G. A. Peterson. 2003. Evaluation of GPFarm for dryland cropping systems in eastern Colorado. Agronomy Journal 95:15101524.

Ascough, J. C., III, M. J. Shaffer, D. L. Hoag, G. S. McMaster, G. H. Dunn, L. R. AhuJA, and M. A. Weltz. 2002. GPFARM: An integrated decision support system for sustainable Great Plains agriculture. In: D.E. Stott, R.H. Mohtar, and G.C. Steinhardt [eds.]. Sustaining the global farm-local action for land leadership: Selected papers from the 10th International Soil Conservation Organization (ISCO) Conference; 24-29 May 1999, Purdue Univ., West Lafayette, IN. West Lafayette, IN: International Soil Conservation Organization in cooperation with the USDA and Purdue University. p 951-960.

Farahani, H. J., AND L. R. Ahuja. 1996. Evapotranspiration modeling of partial canopy/residue-covered fields. Transactions of the American Society of Agricultural Engineers 39:2051-2064.

Gill, R. A., I. C. Burke, D. G. Milchunas, and W. K. Lauenroth. 1999. Relationship between root biomass and soil organic matter pools in the shortgrass steppe of eastern Colorado: implications for decomposition through a soil profile. Ecosystems 2:226-236.

Hanson, J. D., B. B. Baker, and R. M. Bourdon. 1992. SPUR2 documentation and user guide. GPSR Technical Report No. 1. USDA-ARS, Fort Collins, C0. 43 p.

Hanson, J. D., J. W. Skiles, and W. J. Parton. 1987. Plant component. In: J. R. Wight and J. W. Skiles [eds.] SPUR simulation of production and utilization of rangelands: Documentation and user guide USDA-ARS. ARS-63. Springfield, VA: National Technical Information Service. p 57-74.
Hanson, J. D., J. W. Skiles, and W. J. Parton. 1988. A multispecies model for rangeland plant communities. Ecological Modelling 44:89-123.

HART, R. H. 1989. SMART: a simple model to assess range technology. Journal of Range Management 42:421-424.

Lauenroth, W. K. and 0. E. Sala. 1992. Long-term forage production of North American shortgrass steppe. Ecological Applications 2:397-403.

McMaster, G. S., J. C. Ascough II, G. H. Dunn, M. A. Weltz, M. J. Shaffer, D. Palic, B. C. Vandenberg, P. N. S. Bartling, D. Edmunds, D. L. Hoag, and L. R. Ahuja. 2002. Application and testing of GPFARM: A farm and ranch decision support system for evaluating economic and environmental sustainability of agricultural enterprises. Acta Horticulturae 593: 171-177.

McMaster, G. S., J. C. Ascough II, M. J. Shaffer, L. A. Deer-Ascough, P. F. Byrne, D. C. Nielsen, S. D. Haley, A. A. Andales, and G. H. Dunn. 2003. GPFarm plant model parameters: complications of varieties and the $G \times E$ interaction in wheat. Transactions of the American Society of Agricultural Engineers 46: 1337-1346.

Monson, R. K., R. O. Littlejohn, JR., and G. J. Williams III. 1983. Photosynthetic adaptation to temperature in four species from the Colorado shortgrass steppe: a physiological model for coexistence. Oecologia 58:43-51.

Monson, R. K., M. R. Sackschewsky, and G. J. Williams III. 1986. Field measurements of photosynthesis, water-use efficiency, and growth in Agropyron smithii $\left(\mathrm{C}_{3}\right)$ and Bouteloua gracilis $\left(\mathrm{C}_{4}\right)$ in the Colorado shortgrass steppe. Oecologia 68:400-409.

Shaffer, M. J., P. N. S. Bartling, and J. C. Ascough II. 2000. Object-oriented simulation of integrated whole farms: GPFARM framework. Computers and Electronics in Agriculture 28:29-49.

Stevenson, A., R. E. Baumgartner, and G. E. Schuman. 1984. High Plains Grasslands Research Station detailed soil survey. Laramie, WY: USDA-ARS, Wyoming Agricultural Experiment Station, USDA-SCS. 100 p.

VanAmbURG, L. K. 2003. Digital imagery to estimate canopy characteristics of shortgrass prairie vegetation [master's thesis]. Fort Collins, C0: Colorado State University. $122 \mathrm{p}$.

Weaver, J. E., V. H. Houghen, and M. D. Weldon. 1935. Relation of root distribution to organic matter in prairie soil. Botanical Gazette 96:389-420.

WIGHT, J. R., AND J. W. SKILES [EDS.]. 1987. SPUR: Simulation of production and utilization of rangelands. Documentation and user guide. USDA-ARS, ARS 63. Springfield, VA: National Technical Information Service. 367 p.

Wilımott, C. J. 1981. On the validation of models. Physical Geography 2:184-194. WiLlmotT, C. J. 1982. Some comments on the evaluation of model performance. Bulletin of the American Meteorological Society 63:1309-1313.

Willmott, C. J., AND D. E. Wicks. 1980. An empirical method for the spatial interpolation of monthly precipitation within California. Physical Geography 1:59-73. 